\title{
AN ANALYTICAL STUDY ON IMPACT OF INDUSTRIAL EFFLUENT ON THE KHARUN RIVER, RAIPUR, CHHATTISGARH
}

\author{
Manoj Kumar Tiwari \\ Associate Professor, Department of Civil Engineering, SSTC - SSGI-FET, Bhilai, CG (India) \\ nitr.mkt@gmail.com
}

\begin{abstract}
An analysis was done of five water samples collected from study area, during February - March 2015. The high concentration of alkalinity $(209 \mathrm{mg} / \mathrm{L})$ and hardness $(220 \mathrm{mg} / \mathrm{l})$ shows the severe condition of river water due to discharge of Industrial effluent. Heavy metal or toxic metal concentration was found negligible while in sample no 1 the concentrations of $\mathrm{Pb}(0.811 \mathrm{mg} / \mathrm{l}), \mathrm{Cr}$ $(0.642 \mathrm{mg} / \mathrm{l}), \mathrm{Fe}(0.498 \mathrm{mg} / \mathrm{l}), \mathrm{Zn}(0.326 \mathrm{mg} / \mathrm{l})$ and $\mathrm{Mn}(0.3 \mathrm{mg} / \mathrm{l})$. In other locations some metal concentrations were found below the detectable limit although iron appeared in a small quantity. Hence it is concluded that there is an adverse condition of river water environment due to industrial activities and industrial effluent discharge without treatment be supposed to be stopped to protect the valuable river water from contamination.
\end{abstract}

Keywords: Waste Water, Industrial, Heavy Metals, Concentration, Kharun River, Pollution

\section{INTRODUCTION}

Industrialization and urbanization is need of development strategies, but it is also generate a large quantity of wastes and resulted into contamination of the available water wealth. Industrial wastes are complex combination of different contaminants or pollutants (Oyewo, 1998). Water is a precious and principal constituent of the environment which is vital for life and urbanization. During last few decades the water demands rises due to population growth and rapid industrialization (Yisa, J. and T. Jimoh, 2010). River water is a main resource for human as well as industrialization. Unfortunately, river water gets polluted severely because of increased human activities like disposal of sewerage, industrial waste and plethora of human activities, which will also, affects their physico-chemical characteristics and microbiological quality (Koshy and Nayar, 1999; Kolawole et al, 2011). Water resources situated near industrial vicinity have been principally affected by unscientific release of industrial waste, which can alter the quality of water body. Hence, the wastes generated by industrial activities are the main universal sources of water pollution in the current scenario and it might augment yearly due to the fact that new industries are growing and expanding to meet the demands of the general public (O. Osibanjio O. et al., 2011). An industrial waste originates from the industries which have need of large amount of space for treatment, processing and its disposal. Therefore most of the industries are to be found in the vicinity of water sources (Adekunle A. and Eniola T., 2011). Waste water generated from an industry may include sanitary waste, process wastes, wash waters and comparatively unpolluted water from heating and cooling operations. Higher concentration of pollutants in river water systems is responsible for an increase in Biological Oxygen Demand, Chemical Oxygen Demand, Total Solids, Toxic Heavy Metals like; $\mathrm{Cd}, \mathrm{Cr}, \mathrm{Ni}$ and $\mathrm{Pb}$ and fecal coliform and make water unsuitable for consumption of public, irrigation and aquatic life (Trivedi R. C. et al., 2008 ). Waste water generated by the respective industries is the key source of water pollution. Contaminated air, soil, and water are associated with disease burden and this may perhaps be the reason for the current shorter life anticipation in growing countries (WHO CEHA, 2002; WHO).

The study area: - Siltara industrial area is located at a distance of about $10 \mathrm{~km}$ from capital of Chhattisgarh, Raipur having about 97 industries and is situated on NH200. The whole industrial area spread over an area of 1300 hectares (ha) with small and medium scale industries. Average capacity of a sponge iron plant in the cluster is 0.084 MTPA with total installed capacity of the cluster is 2.92 MTPA. The biggest plant here is Godawari Power and Ispat with a capacity of 0.495 MTPA followed by SKS Ispat (0.27 MTPA) (CSIDC).

Main industries located in the study area are sponge iron, Ferro alloy, and cooking gas bottling plant. Through private sector involvement, arrangement has been made to provide constant water supply from the Kharun River. Adjacent habitation is located at a distance of about $1.4 \mathrm{~km}$ from the industrial area. Nearest surface water sources are Chhokhara Nallah and River Kharun flowing at the distance of about $1.25 \& 2.2 \mathrm{Km}$ respectively from the industrial site. So, the whole waste water from the industries is discharged into the nearest ponds or chhokhara nallah (CSIDC). 


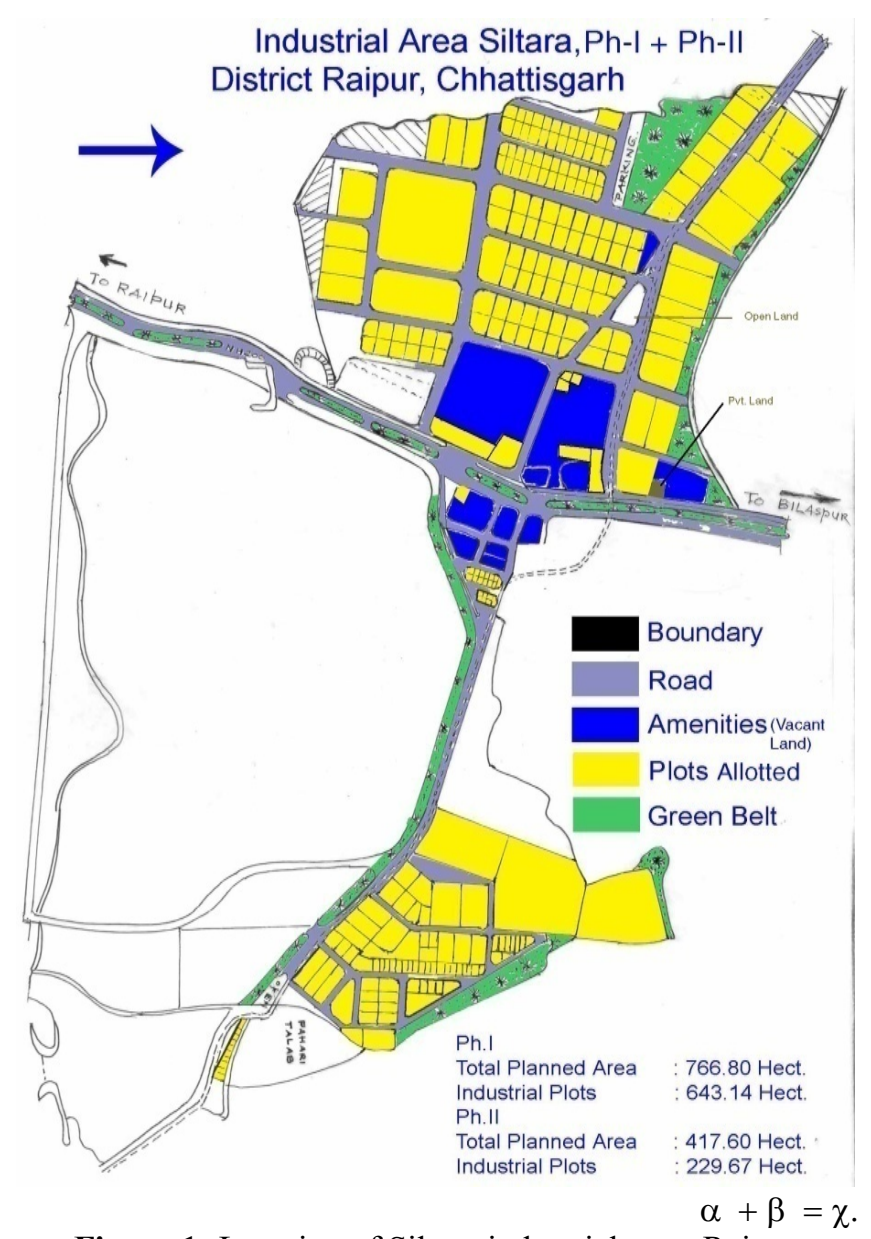

Figure 1: Location of Siltara industrial area, Raipur (Source: CSIDC)

\section{METHODOLOGY}

All samples were collected from five locations (figure 2) in $500 \mathrm{ml}$ plastic bottles during mid-day from effluent channels

leading to the stream and from five Sampling sites along river including Chhokhara Nallah which is directly connected to Kharun River. Each bottle was rinsed with the river water before the final sample collection. A water sample was also collected.

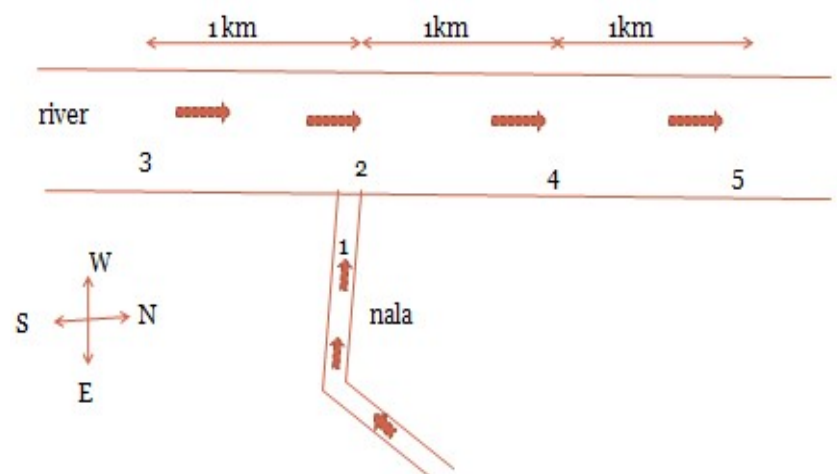

Figure 2: Water sampling location

Samples were analyzed for both physical and chemical characterization. Physical parameters such as temperature, color, odor, total suspended solids, conductivity, and turbidity (Table I) were analyzed. The chemical analysis parameter includes $\mathrm{pH}$, total dissolved solids, hardness, iron, chloride, total alkalinity and chemical oxygen demand.

Temperature and $\mathrm{pH}$ was measured at the point of collection using digital handy thermometer and $\mathrm{pH}$ meter. In laboratory turbidity was determined by a turbidity meter. A conductivity meter was used to determine the conductivity $\&$ TDS. Chemical parameters were analyzed using traditional method of titration. Atomic Absorption Spectrophotometer (VARIAN Model) was utilized for metal concentration determination.

\section{RESULTS AND DISCUSSION}

Table 1- Summary of Physical and chemical analysis of River water samples

\begin{tabular}{|c|c|c|c|c|c|c|}
\hline Parameter & Standard & Location 1 & Location 2 & Location 3 & Location 4 & Location 5 \\
\hline TDS & $500.00(\mathrm{IS}: 1025)$ & 240.00 & 284.00 & 134.00 & 129.0 & 116.0 \\
\hline Alkalinity & $200 \mathrm{mg} / \mathrm{L}$ & $\mathbf{2 0 9 . 0 0}$ & 116 & 186.00 & 175.0 & 175.0 \\
\hline Hardness & $100 \mathrm{mg} / \mathrm{L}$ & $\mathbf{2 2 0 . 0}$ & $\mathbf{1 5 0 . 0}$ & $\mathbf{1 7 0 . 0 0}$ & $\mathbf{1 7 0 . 0}$ & $\mathbf{1 7 0 . 0}$ \\
\hline Chloride & $250 \mathrm{mg} / \mathrm{L}$ & 78.00 & 58.49 & 75.0 & 79.00 & 79.00 \\
\hline Nitrate & $10 \mathrm{mg} / \mathrm{L}$ & 1.80 & 0.03 & 2.90 & 2.00 & 2.00 \\
\hline DO & $2.0(\mathrm{Min})$ & 4.160 & 4.52 & 4.20 & 4.00 & 4.00 \\
\hline COD & $250 \mathrm{mg} / \mathrm{L}$ & 98.00 & 68.00 & 22.01 & 76.33 & 96.33 \\
\hline Turbidity & Clear & 4.0 & 30.0 & 2.0 & 15.0 & 15.0 \\
\hline TSS & $10 \mathrm{mg} / \mathrm{l}$ & 42.0 & 53.0 & 38.0 & 34.0 & 34.0 \\
\hline pH & 6.8 & 7.14 & 8.35 & 7.39 & 7.45 & 7.40 \\
\hline Conductivity & - & 0.46 & 0.26 & 0.26 & 0.26 & 0.27 \\
\hline
\end{tabular}

These conclusion be capable of validate the low alkalinity value of the entire the water samples, since a water having high alkalinity can make it turbid. In the present investigation, the turbidity values vary from 2.0 to $30 \mathrm{NTU}$. The sample 2 has 30.0 NTU of turbidity. All results are well and within the limits. The result of alkalinity, hardness, TSS and $\mathrm{pH}$ has higher values due to raw effluent discharge into the river. The $\mathrm{pH}$ values of all the water samples indicated the alkaline nature of river water. The acidic $\mathrm{pH}$ value cause severe effects to water bodies, woodland, soil resources and human being health. The waste water samples have shown the variation in (34-53.00 $\mathrm{mg} / \mathrm{L}) \mathrm{TSS}$. The sample 2 showed a higher concentration of TSS $(53.00 \mathrm{mg} / \mathrm{L})$. 
Table 2: Results of metal analysis of water samples

\begin{tabular}{|c|c|c|c|c|c|}
\hline \multicolumn{6}{|c|}{ Trace/Toxic Heavy Metal Concentration (mg/l) } \\
\hline Heavy Metals & Sample 1 & Sample 2 & Sample 3 & Sample 4 & Sample 5 \\
\hline $\mathrm{Zn}$ & 0.326 & 0.115 & 0.02 & 0.04 & 0.08 \\
\hline $\mathrm{Cr}$ & 0.642 & 0.07 & BDL & BDL & 0.12 \\
\hline $\mathrm{Pb}$ & 0.811 & 0.108 & BDL & BDL & 0.009 \\
\hline $\mathrm{Fe}$ & 0.498 & 0.097 & 0.002 & BDL & 0.09 \\
\hline $\mathrm{Mn}$ & 0.3 & 0.008 & 0.02 & 0.01 & 0.08 \\
\hline
\end{tabular}

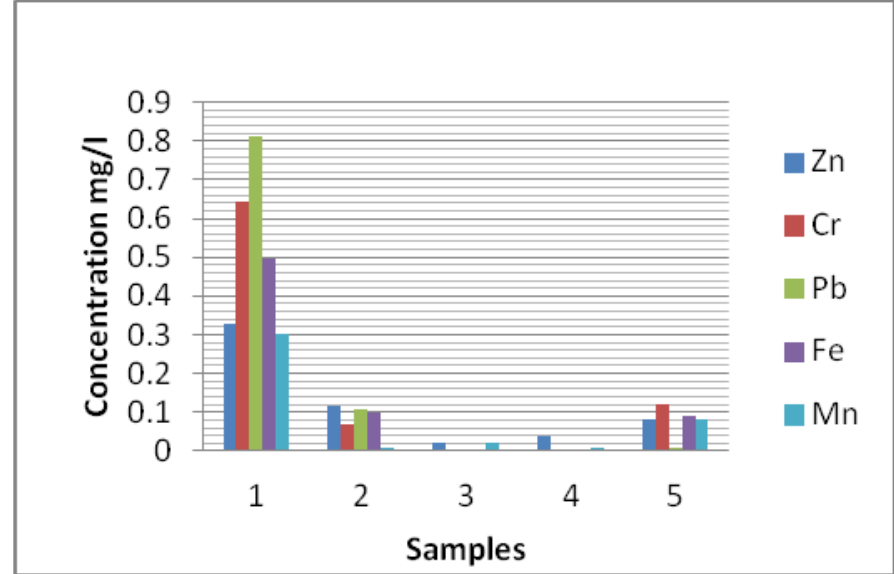

Figure 3: Results of metal analysis of water samples

In the present investigation, the heavy metal concentration value of sample 1 is more as comparison of others samples with maximum amount of $\mathrm{Pb}(0.811 \mathrm{mg} / \mathrm{l}), \mathrm{Cr}(0.642 \mathrm{mg} / \mathrm{l})$, Fe $(0.498 \mathrm{mg} / \mathrm{l}), \mathrm{Zn}(0.326 \mathrm{mg} / \mathrm{l})$ and $\mathrm{Mn}(0.3 \mathrm{mg} / \mathrm{l})$. The location of sample 1 was the junction of effluent stream and the river Kharun.

\section{CONCLUSIONS}

The results of this study indicate that rapid industrialization to meet the future demand in the study areas generate unsympathetic environmental impacts on natural resources in Chhattisgarh. This study is resulted in the little pollution due to industrial activity in Kharun River water. The heavymetal concentrations (Table 2) of the water samples are to a certain extent within the range of WHO standard. Finally it is recommended that the proper treatment of industrial effluent is essential in the study area before discharging, to conserve river water to be suitable for human being as well as aquatic life and industrial purpose.

\section{ACKNOWLEDGMENTS}

The authors are thankful to the Department of civil engineering, NIT Raipur for his kind support and encouragement regarding this work.

\section{REFERENCES}

[1] Adekunle A. and Eniola T.,2011, Impact of Industrial Effluents on Quality of Segment of Asa River Within An Industrial Estate In Ilorin, Nigeria, New York Science Journal, 2010, 1(1): 17-21.

[2] CSIDC, http://csidc.in/siltaramap.htm
[3] Gyawali S., Techato K., Yuangyai C., 2012, Effects of Industrial Waste Disposal on the Surface Water Quality of U-tapao River, Thailand, 2012 International Conference on Environment Science and Engieering, IPCBEE vol.32(2012) (C) (2012)IACSIT Press, Singapoore

[4] Koshy M., Nayar T.V., 1999, Water quality aspects of River Pamba, Pollut. Res. 1999;18:501-510.

[5] Kolawole O. M., Kolawole T. A., Olayemi A. B.,OKOH A. I., 2011, ASSESSMENT OF WATER QUALITY IN ASA RIVER (NIGERIA) AND ITS INDIGENOUS CLARIAS GARIEPINUS FISH, INT J ENVIRON RES PUBLIC HEALTH. 2011 Nov; 8(11): 4332-4352.

[6] R. C. Trivedi, R.M. Bhardwaj and S. Agrawal, Biological Monitoring of Water Quality in India-Needs and Constraints. Proceeding of Taal 2007 2008, 1-6.

[7] O. Osibanjio, O. Daso and A.M. Ghadebo. The Impact of industries on surface water quality of River Ona and River Aloro in Oluyoke Industrial Estate, Ibadan, Nigeria. African Journal of Biotechnology. 2011, 10(4): 696- 702.

[8] Oyewo EO, 1998, Industrial sources and distribution of heavy metals in Lagos Lagoon and their biological effects on Estuarine animals, (Ph.D. Thesis.) University of Lagos, 274 pp. Olobaniyi S.B. and Efe S.I. Journal of Environmental Health Research. 2007. 6(2). 111-118p.

[9] WHO CEHA, 2002, Water Pollutants: Biological Agents, Dissolved Chemicals, Non-dissolved Chemicals, Sediments, Heat, WHO CEHA (2002), Amman, Jordan.

[10] WHO, The World Health Report: Shaping the Future, World Health Organization, (2003) 1211Geneva 27, Switzerland

[11]Yisa, J. and T. Jimoh, 2010. Analytical studies on water quality index of river Landzu. Am.J.AppliedSci.,7:453458.DOI:10.3844/ajassp.2010.453. 